\title{
Characteristics and Preparation Method of Sulfur Extended Asphalt Mixtures
}

\author{
Vahid Rezvani, Hassan Saghi \\ Department of Civil Engineering, Hakim Sabzevari University, Sabzevar, Iran \\ Email address: \\ vahidrezvani2002@gmail.com (V. Rezvani),h.saghi@hsu.ac.ir (H. Saghi)
}

\section{To cite this article:}

Vahid Rezvani, Hassan Saghi. Characteristics and Preparation Method of Sulfur Extended Asphalt Mixtures. American Journal of Civil Engineering. Special Issue: Research and Practices of Civil Engineering in Developing Countries. Vol. 3, No. 2-2, 2015, pp. 69-74. doi: 10.11648/j.ajce.s.2015030202.24

\begin{abstract}
Huge amount of sulfur production as a side product in petrochemical industries and its low application in country has been a challenging issue. In this paper, application of sulfur as a partial substitute for bitumen in process of asphalt mixture production is investigated. According to the results, the characteristics of the sulfur extended asphalt in comparison with the conventional asphalt made from pure bitumen, and the impact of sulfur addition on asphalt performance are expressed and the optimized formula for making the asphalt mixture is obtained. In this content, the modified asphalt was produced in mass production scale and its performance was studied. In this paper, the method of sulfur addition to pure bitumen and then its mixture with aggregate and finally optimized condition of sulfur modified asphalt production regarding pollution and environmental issues are also proposed.
\end{abstract}

Keywords: Sulfur Extended Asphalt, Sulfur Asphalt Concrete, Sulfur, Bitumen, Asphalt

\section{Introduction}

Sulfur recovery from fossil fuel for prevention of air pollution and corrosion in devices has led to production of huge amount of sulfur in the related industries. Sulfur production is particularly significant in gas and oil refining industries and many of them have no use. On the other hand, exportation of this material has its own problems in some of refineries and in most cases is not economically efficient. Predictions show that annual sulfur production in Iran and rest of the world is increasing due to environmental limitation and gradual acetifying of hydrocarbon resources. Therefore studies have been conducted on application of excess sulfur; among them is its application in road construction.

\section{Related Study}

Application of sulfur in road construction has almost hundred-year history. The first approach was in the 1970s following the energy crisis which led to construction of tens of experimental sulfur modified asphalts throughout the world. First sulfur extended asphalts were made in USA and Canada through the 1970s [1, 2]. Then by 2002, about 4200 $\mathrm{km}$ of sulfur asphalts were made and tested in more than 200 countries [3, 4]. Among these countries, USA, England, France, Poland, Spain, Finland, Belgium, Norway, Iraq, Saudi Arabia could be mentioned [5-7]. Experimental construction of sulfur asphalts decreased in the 1980s however, at the end of th 1990, it increased again. The reason is the change in relative cost of sulfur/bitumen in this period of time which provided the economic justification for producing sulfur extended asphalt. In Iran, research studies were made from the 1970s. The results of performance investigation of sulfur asphalt all around the world shows that it has equivalent or better performance in comparison with the ordinary ones.

\section{Theory}

\subsection{Sulfur Properties}

Pure sulfur is a yellow solid which melts at $119^{\circ} \mathrm{C}$ and its viscosity suddenly increases at $160^{\circ} \mathrm{C}$. At high temperatures, sulfur produces toxic gases such as $\mathrm{SO}_{2}$. At specific temperature and conditions, in combination with water, this material produces sulfuric acid which is highly corrosive. 


\subsection{Sulfur Role in Chemical Structure of Bitumen and Its Properties}

The reaction between sulfur and bitumen depends on temperature and sulfur concentration. At its melting point, it has octet ring form and at higher temperatures it forms polymer and gets the form of 2-radical chain. Radicals could react with bitumen in two ways; forming carbon-sulfur bond or absorbing hydrogen and consequently dehydrogenization occurs. The probability of all these reactions depend on temperature therefore, the product would be different. At $240^{\circ} \mathrm{C}$, sulfur acts like Oxygen and the main reaction will be oxidation and $\mathrm{H}_{2} \mathrm{~S}$ would be released. While at $140{ }^{\circ} \mathrm{C}$, the dominant reaction is entrance of sulfur atoms into aromatic naften molecules of bitumen. As a result, the amount of aromatic naften group of bitumen decrease and percentage of polar aromatic groups of bitumen increases. Consequently, the bitumen gets softer and more adhesive. It must be noted that at $140^{\circ} \mathrm{C}$, all the added sulfur do not participate in reaction, part of it will remain in solution form and the rest will float in bitumen. The percentage of the sulfur participating in reaction depends on sulfur concentration, aromatic naften part of bitumen and as a result the type of the bitumen. Therefore, addition of sulfur to bitumen at $140^{\circ} \mathrm{C}$ has the following stages:

Sulfur entrance into chemical structure of bitumen, sulfur solvation in bitumen, suspension of excess sulfur in the form of colloidal particles and finally, sulfur tendency to precipitate.

\section{Impact of Sulfur Addition to Asphalt Mixtures}

\subsection{Asphalt Concrete}

As the majority of warm asphalt used all around the world is asphalt concrete type, application of sulfur in asphalt concrete has gained more attention, in a way that most of the implemented sulfur asphalts in different countries are the sulfur extended asphalt concrete type, as a results most of the reports are on the effect of sulfur addition on the performance characteristics of asphalt concrete. The following results have been obtained from the previous researches:

- Enhancement of some of mechanical properties such as increase in Marshal stability, increase of hardness, increase of resistance against rutting and decrease of transverse cracks in sulfur modified asphalt $[13,17,18]$

- Increase in durability of sulfur asphalt in comparison with ordinary asphalt concrete [2]

- Ease of application and improvement of workability after the addition of sulfur to asphalt [2]

- Decrease of energy costs in asphalt production by reduction of mixing temperature [2].

- Higher resistance against petrol solvents [12]

\subsection{Sand Asphalt}

As sand asphalt has lower quality and strength in comparison with ordinary ones, they have no application in asphalt layers of high traffic paths. The results show that addition of sulfur to sand asphalt will increase its strength significantly in a way that it could be used in the asphalt layers of high traffic roads. Moreover, by application of sulfur, a proper mixture could be make out of desert sand and bitumen which has sufficient strength for use in major roads. In some studies the mixture including $82 \%$ sand, $6 \%$ bitumen and $12 \%$ sulfur is mentioned. Due to high amount of sulfur, this mixture hardens quickly therefore it could be used for road maintenance and let the cars to pass the road quickly after the repairing procedure [14].

\section{Sulfur Extended Asphalt Preparation Methods}

Sulfur could be added to the asphalt mixture in different stages of preparation; following methods are mentioned in studies:

\subsection{Previous Mixing of Sulfur and Bitumen}

Sulfur added bitumen is added to hot aggregate in mixer as follows:

Mixing of hot bitumen and melted sulfur is done by application of colloidal mill, vane stirrer, mixing in the path or in weighing container. Each method has its own advantages and disadvantages.

Mixing of hot bitumen and solid sulfur in a way that the solid sulfur enters melted bitumen and after contact with bitumen it melts and properly distributed in bitumen by powerful stirrers. Finally sulfur added bitumen would be conducted to mixer [15].

\subsection{Direct Addition of Sulfur to the Mixer of Asphalt Plant}

In this method, solid or liquid sulfur, after being weighed, is directly injected to mixer; in this way, the containers needed for liquid sulfur or premixing of sulfur and bitumen (which leads to production of $\mathrm{H}_{2} \mathrm{~S}$ ) would be eliminated, therefore the emission would be reduced and the work would be done more easily [16].

According to studies, direct mixing is more popular due to less emission. In this method, sulfur would be transported by conveyor belt to the top of mixer, and after direct weighing; it would be poured on mixture of aggregate and hot bitumen and properly mixed.

\section{Experimental Investigations}

Before the production of sulfur asphalt in industrial scale, it is needed to obtain the technical parameters such as temperature, optimized percent of bitumen and sulfur, method of mixing, design of asphalt mixture and so on. In this regard, numerous mixtures were prepared and the results are presented here. In order to achieve to a uniform and homogeneous mixture, the method of mixing melted bitumen (60/70 pure bitumen of Isfahan refinery) and solid sulfur was 
selected. It must be noted that the mixture of bitumen and sulfur should be enough in a way that it could be uniformly distributed and any crystal bump of sulfur should be prevented. Sulfur added bitumen is relatively unstable and should be considered as an intermediate product rather than a product suitable for storing. Microscopic investigations showed that the amount of dissolved sulfur in bitumen is independent of bitumen grade and it was not crystallized by passing of time.

\subsection{Experimental Results of Sulfur Addition to Bitumen}

Results showed in table 1 are related to the mixtures prepared in this paper:

Table 1. Physical characteristics of pure and sulfur added bitumen.

\begin{tabular}{|c|c|c|c|c|c|c|c|c|c|c|c|}
\hline No. & $\begin{array}{l}\text { Pure } \\
\text { Bitumen } \\
60 / 70(\%)\end{array}$ & $\begin{array}{l}\text { Sulfur } \\
\text { (\%) }\end{array}$ & $\begin{array}{l}\text { Softening } \\
\text { Point }\left({ }^{\circ} \mathbf{C}\right)\end{array}$ & $\begin{array}{l}\text { Weight loss } \\
\text { due to } \\
\text { heating } \\
(\mathrm{w} \%)\end{array}$ & $\begin{array}{l}\text { Penetration } \\
\text { in } 25^{\circ} \mathrm{C} \\
(0.1 \mathrm{~mm})\end{array}$ & $\begin{array}{l}\text { Ductility } \\
\text { in } 4^{\circ} \mathrm{C} \\
\text { (cm) }\end{array}$ & $\begin{array}{l}\text { Ductility } \\
\text { in } 15^{\circ} \mathrm{C} \\
(\mathrm{cm})\end{array}$ & $\begin{array}{l}\text { Ductility } \\
\text { in } 25^{\circ} \mathrm{C} \\
(\mathrm{cm})\end{array}$ & $\begin{array}{l}\text { Relative } \\
\text { Specific } \\
\text { Gravity } \\
\text { in } 25^{\circ} \mathrm{C}\end{array}$ & $\begin{array}{l}\text { Flash } \\
\text { point } \\
\left({ }^{\circ} \mathrm{C}\right)\end{array}$ & $\begin{array}{l}\text { Fraass } \\
\text { breaking } \\
\text { point }\left({ }^{\circ} \mathrm{C}\right)\end{array}$ \\
\hline 1 & 100 & 0 & 49.5 & 0.01 & 65 & 0 & 96 & +150 & 1.015 & 339 & -11 \\
\hline 2 & 85 & 15 & 48 & 0.71 & 92 & 2 & 31 & +100 & 1.103 & 215 & -12 \\
\hline 3 & 75 & 25 & 46.5 & 0.82 & 93 & 2 & 25 & 39 & 1.143 & 205 & -12 \\
\hline 4 & 65 & 35 & 48 & 0.91 & 94 & 1 & 24 & 36 & 1.100 & 201 & -10 \\
\hline 5 & 55 & 45 & 48 & 0.98 & 93 & 1.5 & 19 & 24 & 1.316 & 191 & -7 \\
\hline
\end{tabular}

\begin{tabular}{lllllll}
\hline RTFO & & & & & \\
\hline $\begin{array}{l}\text { Viscosity in } \mathbf{6 0}^{\circ} \mathbf{C} \\
(\text { poise })\end{array}$ & $\begin{array}{l}\text { Viscosity in } \\
\mathbf{1 3 5}^{\circ} \mathbf{C}(\mathbf{c S t})\end{array}$ & $\begin{array}{l}\text { Viscosity in } \\
\mathbf{9 8 . 9}{ }^{\circ} \mathbf{C}(\mathbf{c S t})\end{array}$ & $\begin{array}{l}\text { Ductility in } \mathbf{2 5}{ }^{\circ} \mathbf{C} \\
(\mathbf{c m})\end{array}$ & $\begin{array}{l}\text { Softening point } \\
\left({ }^{\circ} \mathbf{C}\right)\end{array}$ & $\begin{array}{l}\text { Penetration in } \\
\mathbf{2 5}^{\circ} \mathbf{C}(\mathbf{0 . 1} \mathbf{~ m m})\end{array}$ & $\begin{array}{l}\text { Weight loss due } \\
\text { to heating (w\%) }\end{array}$ \\
\hline 1372 & 330 & 2422 & 100 & 54 & 39 & 0.04 \\
908 & 133 & 1125 & 68 & 55 & 41 & 4.1 \\
1119 & 154 & 1371 & 33 & 56 & 41.50 & 4.57 \\
2188 & 232 & 2851 & 24 & 57 & 39 & 4.84 \\
764 & 174 & 1091 & 21 & 58 & 37.5 & 4.59 \\
\hline
\end{tabular}

\subsubsection{Penetration Grade}

As it was mentioned before, by addition of sulfur, bitumen would get softer and more penetrative. Addition of 5\% sulfur will result in significant increase in its penetration, but by gradual increase of sulfur to $45 \%$, no significant increase in penetration would be observed. High increase in sulfur content would lead to lower penetration, even less than the basic pure bitumen.

\subsubsection{Softening Point}

Due to conversion of aromatic naften part of the bitumen into polar aromatic and constant ratio of asphalteness to saturated hydrocarbon in the procedure of adding sulfur to bitumen, no significant change could be observed in softening point.

\subsubsection{Ductility}

By increasing the ratio of sulfur to bitumen, ductility would be reduced in high temperatures $15,25^{\circ} \mathrm{C}$ ), but in lower temperatures, ductility will improve. It is noted, by increasing of sulfur content, significant changes in the rate of this feature are not observed.

\subsubsection{Effect of Temperature on Sulfur Added Bitumen}

Results of weight reduction due to heating indicate that higher percent of sulfur in bitumen will result in more weight dissipation. As a result, reduction in penetration of sulfur added bitumen after the experiment would be more than the pure bitumen. This trend was also observed in RTFO experiment.

\subsubsection{Viscosity}

By addition of sulfur, viscosity also decreases, but by reach of sulfur content to $35 \%$, it will increase and approaches to value of pure bitumen, by further increase of sulfur, viscosity will decrease again.

\subsection{Asphalt Concrete}

According to experimental researches, in order to avoid emission of harmful gases such as $\mathrm{H}_{2} \mathrm{~S}$, the temperature of sulfur added bitumen would be never more than $150^{\circ} \mathrm{C}$. This would make no problem in preparation procedure of sulfur asphalt and it is only due to improvement of rheological properties of bitumen. The next stages of sulfur addition to asphalt concrete such as the method of sulfur addition, determination of the best condition of mixing, and obtaining the best practical formula were investigated for sulfur added bitumen with different percent of sulfur. After comparing the results with pure bitumen, the data were analyzed and at the next stage, the effect of sulfur on adhesive properties of bitumen to mineral aggregate, in presence of water, was studied. As viscosity of sulfur added bitumen is less than pure one, the temperature of mixing and compacting the sulfur extended asphalt mixture would be less than pure one. 
In this study, the temperature of mixing is $140-145{ }^{\circ} \mathrm{C}$, and the temperature of compacting is $130-135{ }^{\circ} \mathrm{C}$. As specific gravity of sulfur is twice the bitumen; the following equation could be applied for obtaining weight percentage of sulfur added bitumen:

$$
S E A \%=\frac{S G S A / S G A * P A * 100}{S G S A / S G A * P A+(100-P A)}
$$

Where, $S G_{S A}$ is specific gravity of sulfur added bitumen, $S G_{A}$ is specific gravity of pure bitumen, $P_{A}$ is weight percentage of bitumen in conventional mix design and $S E A \%$ donates the required weight percentage of sulfur added bitumen.

\subsection{Preparation of Asphalt Mixture}

The design of asphalt mixture with $60 / 70$ pure bitumen and sulfur added bitumen were made in lab. Similar materials were used for preparation of them whose properties are as follows.

Table 2. Gradation and specification.

\begin{tabular}{|c|c|c|c|c|c|c|}
\hline \multicolumn{7}{|l|}{ Percent Passing } \\
\hline $\begin{array}{l}\text { Gradation }(1 / 2 \\
\text { inch) }\end{array}$ & $\begin{array}{l}3 / 4 \\
\text { inch }\end{array}$ & $1 / 2$ inch & No. 4 & No. 8 & $\begin{array}{l}\text { No. } \\
50\end{array}$ & $\begin{array}{l}\text { No. } \\
200\end{array}$ \\
\hline $\begin{array}{l}\text { ASTM-D3515 } \\
\text { (Specification } \\
\text { range) }\end{array}$ & 100 & $90-100$ & $44-74$ & $28-58$ & $5-12$ & $2-10$ \\
\hline $\begin{array}{l}\text { ASTM-D3515 } \\
\text { (Specification } \\
\text { midpoint) }\end{array}$ & 100 & 95 & 59 & 43 & 9.5 & 6 \\
\hline $\begin{array}{l}\text { Aggregate } \\
\text { Gradation A }\end{array}$ & 100 & 15 & - & - & - & - \\
\hline $\begin{array}{l}\text { Aggregate } \\
\text { Gradation B }\end{array}$ & 100 & 100 & - & - & - & - \\
\hline $\begin{array}{l}\text { Aggregate } \\
\text { Gradation C }\end{array}$ & 100 & 100 & 90 & 10 & - & - \\
\hline $\begin{array}{l}\text { Aggregate } \\
\text { Gradation D }\end{array}$ & 100 & 100 & 100 & 90 & 6 & 2 \\
\hline Mineral filler & 100 & 100 & 100 & 100 & 80 & 35 \\
\hline $\begin{array}{l}\text { Theoretical } \\
\text { results of } \\
\text { gradation }\end{array}$ & 100 & 91.5 & 68 & 48 & 10.4 & 4.3 \\
\hline $\begin{array}{l}\text { Experimental } \\
\text { results of } \\
\text { gradation }\end{array}$ & 100 & 91 & 69 & 48 & 10 & 4 \\
\hline
\end{tabular}

The results of Marshal Mix Design calculation of the samples made from 60/70 pure bitumen are presented in table 3 .

Table 3. Calculation of Marshal Mix Design for samples made from 60/70 pure bitumen.

\begin{tabular}{llllll}
\hline $\begin{array}{l}\text { Bitument } \\
\text { content } \\
(\%)\end{array}$ & $\begin{array}{l}\text { Stability } \\
\text { value } \\
(\mathbf{k g})\end{array}$ & $\begin{array}{l}\text { Flow } \\
\text { value } \\
(\mathbf{m m})\end{array}$ & $\begin{array}{l}\text { Bulk specify } \\
\text { gravity } \\
\text { (gr/cm3) }\end{array}$ & $\begin{array}{l}\text { Voids in } \\
\text { Mineral } \\
\text { Aggregate (\%) }\end{array}$ & $\begin{array}{l}\text { Air } \\
\text { Voids } \\
(\%)\end{array}$ \\
\hline 4.0 & 1092 & 2.3 & 2.328 & 14.7 & 5.7 \\
4.50 & 1115 & 2.5 & 2.341 & 14.6 & 4.4 \\
5.0 & 1069 & 2.8 & 2.338 & 15.2 & 3.8 \\
5.5 & 1022 & 3.0 & 2.335 & 16.5 & 3.7 \\
6.0 & 999 & 3.3 & 2.324 & 16.6 & 3.6 \\
\hline
\end{tabular}

\begin{tabular}{ll}
\hline Optimum conditions & \\
\hline Bitument content $(\%)$ & 4.6 \\
Stability value $(\mathrm{kg})$ & 1110 \\
Flow value (mm) & 2.5 \\
Bulk specify gravity (gr/cm3) & 2.341 \\
Voids in Mineral Aggregate (\%) & 14.8 \\
Air Voids (\%) & 4.2 \\
\hline
\end{tabular}

Similar calculations were conducted for the samples made from sulfur added bitumen with different content of sulfur $(25,35$ and $45 \%)$ which are presented in tables 4,5 , and 6 .

Table 4. Calculation of Marshal Mix Design for samples made from sulfuric bitumen with $25 \%$ sulfur content.

\begin{tabular}{llllll}
\hline $\begin{array}{l}\text { Bitument } \\
\text { content } \\
(\%)\end{array}$ & $\begin{array}{l}\text { Stability } \\
\text { value } \\
(\mathbf{k g})\end{array}$ & $\begin{array}{l}\text { Flow } \\
\text { value } \\
(\mathbf{m m})\end{array}$ & $\begin{array}{l}\text { Bulk } \\
\text { specify } \\
\text { gravity } \\
\mathbf{( g r / c m 3 )}\end{array}$ & $\begin{array}{l}\text { Voids in } \\
\text { Mineral } \\
\text { Aggregate } \\
(\mathbf{\%})\end{array}$ & $\begin{array}{l}\text { Air } \\
\text { Voids } \\
(\%)\end{array}$ \\
\hline 4.0 & 929 & 2.0 & 2.356 & 14.1 & 6.4 \\
4.50 & 1208 & 2.5 & 2.376 & 13.8 & 5.1 \\
5.0 & 1277 & 2.8 & 2.386 & 13.9 & 4.2 \\
5.5 & 1138 & 2.9 & 2.380 & 14.6 & 4.0 \\
6.0 & 1092 & 2.3 & 2.375 & 15.2 & 3.8 \\
\hline
\end{tabular}

\begin{tabular}{ll}
\hline Optimum conditions & \\
\hline Bitument content $(\%)$ & 5.6 \\
Stability value $(\mathrm{kg})$ & 1260 \\
Flow value $(\mathrm{mm})$ & 2.7 \\
Bulk specify gravity (gr/cm3) & 2.386 \\
Voids in Mineral Aggregate $(\%)$ & 14 \\
Air Voids $(\%)$ & 4.1 \\
\hline
\end{tabular}

Table 5. Calculation of Marshal Mix Design for samples made from sulfuric bitumen with $35 \%$ sulfur content.

\begin{tabular}{|ll|l|l|l|l|}
\hline $\begin{array}{l}\text { Bitument } \\
\text { content } \\
(\%)\end{array}$ & $\begin{array}{l}\text { Stability } \\
\text { value } \\
(\mathbf{k g})\end{array}$ & $\begin{array}{l}\text { Flow } \\
\text { value } \\
(\mathbf{m m})\end{array}$ & $\begin{array}{l}\text { Bulk } \\
\text { specify } \\
\text { gravity } \\
\mathbf{( g r / c m 3 )}\end{array}$ & $\begin{array}{l}\text { Voids in } \\
\text { Mineral } \\
\text { Aggregate } \\
\mathbf{( \% )}\end{array}$ & $\begin{array}{l}\text { Air } \\
\text { Voids } \\
\mathbf{( \% )}\end{array}$ \\
\hline 4.0 & 1069 & 2.4 & 2.357 & 14.0 & 6.4 \\
4.50 & 1092 & 2.5 & 2.380 & 13.7 & 5.0 \\
\hline 5.0 & 1208 & 2.7 & 2.389 & 13.8 & 4.3 \\
\hline 5.5 & 1162 & 2.8 & 2.385 & 14.4 & 4.0 \\
\hline 6.0 & 1045 & 3.0 & 2.381 & 15.0 & 3.8 \\
\hline
\end{tabular}

\begin{tabular}{ll}
\hline Optimum conditions & \\
\hline Bitument content $(\%)$ & 5.6 \\
Stability value $(\mathrm{kg})$ & 1200 \\
Flow value $(\mathrm{mm})$ & 2.6 \\
Bulk specify gravity (gr/cm3) & 2.390 \\
Voids in Mineral Aggregate $(\%)$ & 13.9 \\
Air Voids $(\%)$ & 4.2 \\
\hline
\end{tabular}


Table 6. Calculation of Marshal Mix Design for samples made from sulfuric bitumen with $45 \%$ sulfur content.

\begin{tabular}{llllll}
\hline $\begin{array}{l}\text { Bitument } \\
\text { content } \\
(\%)\end{array}$ & $\begin{array}{l}\text { Stability } \\
\text { value } \\
(\mathbf{k g})\end{array}$ & $\begin{array}{l}\text { Flow } \\
\text { value } \\
(\mathbf{m m})\end{array}$ & $\begin{array}{l}\text { Bulk } \\
\text { specify } \\
\text { gravity } \\
\mathbf{( g r} / \mathbf{c m} 3)\end{array}$ & $\begin{array}{l}\text { Voids in } \\
\text { Mineral } \\
\text { Aggregate } \\
(\%)\end{array}$ & $\begin{array}{l}\text { Air } \\
\text { Voids } \\
(\%)\end{array}$ \\
\hline 4.0 & 1208 & 2.3 & 2.360 & 13.9 & 6.3 \\
4.50 & 1231 & 2.4 & 2.385 & 13.5 & 5.2 \\
5.0 & 1245 & 2.5 & 2.391 & 13.7 & 4.3 \\
5.5 & 1162 & 2.9 & 2.388 & 14.3 & 4.1 \\
6.0 & 1138 & 3.0 & 2.386 & 14.8 & 3.9 \\
\hline
\end{tabular}

\begin{tabular}{ll}
\hline Optimum conditions & \\
\hline Bitument content $(\%)$ & 5.7 \\
Stability value $(\mathrm{kg})$ & 1250 \\
Flow value $(\mathrm{mm})$ & 2.6 \\
Bulk specify gravity (gr/cm3) & 2.392 \\
Voids in Mineral Aggregate $(\%)$ & 13.8 \\
Air Voids $(\%)$ & 4.2 \\
\hline
\end{tabular}

\subsection{Adhesion to Mineral Aggregate}

One of the properties of sulfur added bitumen is the increase of adhesion to mineral aggregate in presence of water. In this content, according to AASHTO method, 95 gr of stones with specific grading was covered with 5 gr of bitumen and then floated in water. At $60{ }^{\circ} \mathrm{C}$, and in specific time intervals, the bitumen cover of aggregate was investigated. As it is observed from table 7, sulfur added bitumen has better adhesion properties in comparison with pure one.

Table 7. Adhesion of pure and sulfur added bitumen to aggregate at presence of water.

\begin{tabular}{|c|c|c|c|c|c|c|}
\hline \multirow[b]{2}{*}{ No. } & \multirow{2}{*}{$\begin{array}{l}\text { Bitumen } \\
\text { type }\end{array}$} & \multirow{2}{*}{$\begin{array}{l}\text { Bitumen } \\
(\%)\end{array}$} & \multirow[b]{2}{*}{$\begin{array}{l}\text { Sulfur } \\
(\%)\end{array}$} & \multicolumn{3}{|c|}{ Percentage of being washed } \\
\hline & & & & $\begin{array}{l}\text { After 1 } \\
\text { h }\end{array}$ & $\begin{array}{l}\text { After } \\
24 \mathrm{~h}\end{array}$ & $\begin{array}{l}\text { After } \\
48 \mathrm{~h}\end{array}$ \\
\hline 1 & $60 / 70$ & 100 & 0 & 60 & 65 & 70 \\
\hline 2 & $60 / 70$ & 75 & 25 & 25 & 45 & 50 \\
\hline 3 & $60 / 70$ & 65 & 35 & 20 & 35 & 40 \\
\hline 4 & $60 / 70$ & 55 & 45 & 5 & 10 & 15 \\
\hline
\end{tabular}

\section{Field Operation}

According to the results, bitumen with $35 \%$ sulfur was prepared at industrial scale and mixed with aggregate to prepare sulfur extended asphalt mixture. Then it was laid down in one of the sub roads of Mashhad-Ghoochan road beside ordinary asphalt pavement. All the materials and road conditions were considered similar with ordinary asphalt pavement, only the optimized percent of bitumen, mixing and compaction temperature were different. Fortunately, due to close care of temperature and safety points, no emissions were observed in location of preparation, transportation or implementation. This piece of road would be evaluated in different seasons in future.

\section{Discussion and Conclusion}

The results of the study could be summarized as follows:

- In spite of bitumen properties modification by addition of sulfur, however, the main motif for application of sulfur is economic reason. Therefore, when the price of sulfur is lower than bitumen, this sounds reasonable.

- Addition of sulfur to pure bitumen will result in modification of some properties of bitumen such as increasing penetration, viscosity reduction and adhesion improvement. And the modified asphalt concrete has higher tension strength.

- Due to viscosity reduction, temperature of mixing and compacting is lower, which leads to energy saving.

- In order to reduce the emission, technical and safety points especially temperature control should be performed [19].

- No emission was observed in this study as the temperature was closely controlled.

- Preparation and implementation of sulfur extended asphalt mixture is possible with current equipment and facilities and no modification is needed, only some consideration should be mentioned for addition of sulfur.

\section{References}

[1] Filippis P.D., "Sulfur-Extended Asphalt, Reaction Kinetics of H2S Evolution", Fuel, Vol. 77, No.5, 1998.

[2] Weber H., "Sulfur- Asphalt \& its Global Aspects", Sulfur Institute, 19th Sulfur Phosphate Symposium, 2003.

[3] Mills D.R., "Field Trial with Sulfur- Extended - Asphalt (SEA) Binders", Sulfur Research \& Development, Vol.3, No.3, 1980.

[4] Nazarbegi Ali Ehsan, "sulfur application in asphalt mixture for roads", research report of oil industry research center 1998.

[5] Strickland D., "Performance Properties of Paving Mixtures Made with Modified Sulfur Pellets", International Symposium on Antennas \& Propagation (ISAP), Taipie, Taiwan, 2008.

[6] Asphalt Institute, "State-of-Knowledge on the Use of SulfurExtended Asphalt (SEA)", 2007.

[7] John S.C., "Review of Relationships between Modified Asphalt Properties and Pavement Performance", SHRP-A-631, 1993.

[8] Love G.D., "Sulfur-Paving Material of the Future", Sulfur Research \& Development, Vol.3, No.3, 1980.

[9] Deme B.H., "Mix-Paver-New Approach to Sulfur Paving", Sulfur Research \& Development, Vol.3, No.3, 1980.

[10] Alikhani, "sulfur use in asphalt and its safety", road development organization, 1999.

[11] Petrossi V., "Reactions \& Technological Properties of Sulfur Treated Asphalt", Industrial Engineering of Chemical Production Research and Development, Vol.11, No.2, 1972.

[12] Miller L.J., "A Technical Review of Sulfur- Association Asphalt Paving Technologists", Vol. 42, 1981. 
[13] Tabatabaei A.M., "sulfur application in asphalt pavement", journal of technical faculty, No 46, 1984.

[14] Parrett F., "Sulfur Extended Asphalt for Highways", Civil Engineering, Vol. 28, 1984.

[15] "Solid Sulfur- Extended Asphalt Composition and Method and Apparatus therefore", U.S. Patent, No.4, 1982.

[16] Taylor J.A., Kennepohl G.J., "Environmental Aspects of Paving with Sulfur-Asphalt", Can. Tech. of Asphalt Assoc., 1980.
[17] Bissada A., "Rheological Characteristics of Sulfur Extended Asphalts used for Road Pavements", Sulfur Research \& Development, Vol.9, 1985.

[18] Kandhal P.S., "Evaluation of Sulfur Extended Asphalt Binders in Bituminous Paving Mixtures", Association of Asphalt Paving Technologists, Vol.51, 1982.

[19] Liddle W. A., Mahoney J.R., "Sulfur Extended Asphalt Pavement Evaluation for the Baker River Highway", FHWA Report, 1983. 